\title{
Potential Benefits of N-Acetylcysteine in Preventing Pregabalin-Induced Seeking-Like Behavior
}

\author{
Atiah H. Almalki 1,2 ${ }^{\mathbb{D}}$, Hashem O. Alsaab ${ }^{2,3}$, Walaa F. Alsanie ${ }^{2,4}$, Ahmed Gaber 2,5 ${ }^{\mathbb{D}, \text { Turki Alkhalifa }}{ }^{6}$, \\ Ahmad Almalki ${ }^{6}$, Omar Alzahrani ${ }^{2}$, Ana Maria Gregio Hardy ${ }^{7}$, Qasim Alhadidi ${ }^{8}$, Zahoor A. Shah ${ }^{9}$ (D) and \\ Yusuf S. Althobaiti $2,6,10, *$ D
}

check for updates

Citation: Almalki, A.H.; Alsaab, H.O.; Alsanie, W.F.; Gaber, A.; Alkhalifa, T.; Almalki, A.; Alzahrani, O.; Hardy, A.M.G.; Alhadidi, Q.; Shah, Z.A.; et al. Potential Benefits of $\mathrm{N}$-Acetylcysteine in Preventing Pregabalin-Induced Seeking-Like Behavior. Healthcare 2021, 9, 376. https://doi.org/10.3390/ healthcare 9040376

Academic Editor: Farhad Kamali

Received: 18 February 2021

Accepted: 18 March 2021

Published: 29 March 2021

Publisher's Note: MDPI stays neutral with regard to jurisdictional claims in published maps and institutional affiliations.

Copyright: (c) 2021 by the authors. Licensee MDPI, Basel, Switzerland. This article is an open access article distributed under the terms and conditions of the Creative Commons Attribution (CC BY) license (https:// creativecommons.org/licenses/by/ $4.0 /)$.
1 Department of Pharmaceutical Chemistry, College of Pharmacy, Taif University, P.O. Box 11099, Taif 21944, Saudi Arabia; ahalmalki@tu.edu.sa

2 Addiction and Neuroscience Research Unit, Taif University, P.O. Box 11099, Taif 21944, Saudi Arabia; h.alsaab@tu.edu.sa (H.O.A.); w.alsanie@tu.edu.sa (W.F.A.); a.gaber@tu.edu.sa (A.G.); O07mar@hotmail.com (O.A.)

3 Department of Pharmaceutics and Pharmaceutical Technology, College of Pharmacy, Taif University, P.O. Box 11099, Taif 21944, Saudi Arabia

4 Department of Clinical Laboratories Sciences, The Faculty of Applied Medical Sciences, Taif University, P.O. Box 11099, Taif 21944, Saudi Arabia

5 Department of Biology, College of Science, Taif University, P.O. Box 11099, Taif 21944, Saudi Arabia

6 Ministry of Interior, General Directorate of Narcotics Control, General Administration for Precursors and Laboratories, Riyadh 11564, Saudi Arabia; Turki2004_25@hotmail.com (T.A.);

Ah1180mad@hotmail.com (A.A.)

7 Department of Physiology and Pharmacology, College of Medicine and Life Sciences, University of Toledo, Toledo, OH 43614, USA; AnaMaria.Hardy@UToledo.Edu

8 Department of Anesthesiology, Perioperative and Pain Medicine, Stanford Medical School, Stanford University, Stanford, CA 94305, USA; qalhad18@stanford.edu

9 Department of Medicinal and Biological Chemistry, College of Pharmacy and Pharmaceutical Sciences, University of Toledo, Toledo, OH 43614, USA; zahoor.shah@utoledo.edu

10 Department of Pharmacology and Toxicology, College of Pharmacy, Taif University, P.O. Box 11099, Taif 21944, Saudi Arabia

* Correspondence: ys.althobaiti@tu.edu.sa; Tel.: +966-545736200

\begin{abstract}
Substance-use disorder is globally prevalent and responsible for numerous social and medical problems. Pregabalin (Lyrica), typically used to treat diabetic neuropathy, has recently emerged as a drug of abuse. Drug abuse is associated with several neuronal changes, including the downregulation of glutamate transporters such as glutamate transporter 1 and cystine/glutamate antiporter. We investigated the effects of $\mathrm{N}$-acetylcysteine, a glutamate transporter 1 and xCT upregulator, on pregabalin addiction using a conditioned place preference paradigm. Pregabalin (60 mg/ $\mathrm{kg}$ ) was found to induce conditioned place preference when compared to a vehicle. A $100 \mathrm{mg} / \mathrm{kg}$ dose of $\mathrm{N}$-acetylcysteine was found to block pregabalin-seeking behaviors. These results support previous findings showing that glutamate transporters play an important role in pregabalininduced seeking behaviors. $\mathrm{N}$-acetylcysteine may represent a beneficial agent in preventing the abuse potential of pregabalin.
\end{abstract}

Keywords: NAC; pregabalin; addiction; GLT-1; xCT; CPP

\section{Introduction}

Pregabalin, a gamma-aminobutyric acid derivative, reduces the release of glutamate by binding to a voltage-gated calcium channel subunit [1]. Pregabalin is predominantly used to treat neuropathy in diabetic patients, anxiety disorder, and partial epilepsy [2,3]. Recently, pregabalin emerged as an illicit drug widely abused throughout the world [4-6], especially among Saudi Arabian youth $[7,8]$. This may be due to the lack of regulations and knowledge about pregabalin's addictive properties. High doses and extended use of 
pregabalin were reported to be associated with euphoria and withdrawal symptoms [9-12]. Althobaiti et al. showed that pregabalin induced conditioned place preference (CPP) and might affect the glutamatergic mechanism when used at doses of $60-90 \mathrm{mg} / \mathrm{kg}$ [13]. It is essential that the mechanisms by which pregabalin induces rewarding effects are further understood.

Glutamate transporters are significantly affected by drug abuse and addiction [14], and glutamate transporter 1 (GLT-1) is accountable for $90 \%$ of glutamate uptake [15]. GLT-1 expression is downregulated in individuals with a history of drug abuse and addiction, and this can provoke alcohol, cocaine, and methamphetamine addiction [16-18]. Conversely, GLT-1 upregulation attenuates drug-seeking behavior [17]. Drug abuse also downregulates the cystine/glutamate antiporter $(x C T)$, which is responsible for glutamate and cysteine exchange in glial cells. Furthermore, GLT-1 and xCT downregulation increases glutamate concentration, which then causes the overactivation of postsynaptic receptors such as mGlu-1 [19] and mGlu-5 [20,21]. In contrast, blocking these receptors in the nucleus accumbens (NAcc), the reward center of the brain [22], is associated with a reduction in both drug-seeking behavior and addiction relapse [23-26].

N-acetylcysteine (NAC), an acetylated form of cysteine and a glutathione (GSH) precursor, is a source of scientific enthusiasm due to its efficacy in drug-addiction treatment $[27,28]$. In humans, NAC is known for its role in mitigating cocaine and nicotine dependence [29-31]. This drug was shown to normalize glutamatergic functions and reduce drug-seeking behavior [32,33]. Likewise, NAC was revealed to diminish heroin drug-seeking effects in rats [34]. NAC, therefore, emerged as a potential candidate for the treatment of nicotine, heroin, and cocaine drug-seeking effects [34-36]. NAC can upregulate GLT-1 and xCT expression, which in turn regulate glutamate homeostasis by increasing the exchanging amount of glutamate by glial cells $[27,37,38]$. Therefore, in this study, we assessed the role of NAC on pregabalin induced-seeking behavior using the conditioned place preference (CPP) paradigm.

The CPP paradigm is a model that was extensively used for studying the preference behavior of animals [39-42]. This model was used to study the effects of several enforcers such as drugs and food. The CPP strategy is characterized by two periods of investigation and two compartments, whereby a reinforcing stimulus during the first period is evaluated during a second (test) period where animals are allowed to choose between the enforcer-paired and nonpaired compartments [41-43]. Even though the CPP experiment is a widely used strategy, there are many variables that may affect the results, such as flooring, apparatus design, experimental design, and cues $[39,43]$. Therefore, in this study, an unbiased CPP where animals showing strong initial preference were excluded from the study to examine the role of NAC on pregabalin induced-seeking like behavior.

\section{Materials and Methods}

\subsection{Animals}

Thirty-six male mice (BALB/c) were purchased from King Fahd Medical Research Center (Jeddah, Saudi Arabia) (weight, 25-30 g) at the beginning of the study. The mice were housed in groups at optimal temperature $\left(21^{\circ} \mathrm{C}\right)$ and humidity $(30 \%)$ levels, with ad libitum access to water and food; they were allowed to acclimate for 1 week before the experiments. All experiments were conducted during the light cycle of 8:00-10:00 a.m.

\subsection{Drugs}

Both pregabalin (kindly provided by the research and development department at Jamjoom Pharma, Jeddah, Saudi Arabia) and NAC (Sigma-Aldrich, St. Louis, MO, USA) were reformulated in normal saline solution $(0.9 \% \mathrm{NaCl})$ before use.

\subsection{Experimental Design}

The experimental scheme is shown in Figure 1. Mice were randomly assigned to 1 of 4 groups treated with different treatment regimens for 8 consecutive days throughout 
the conditioning period. Mice in Group $1(\mathrm{~V}-\mathrm{V}$ group, $n=10)$ were given a vehicle (saline, $10 \mathrm{~mL} / \mathrm{kg}$ ), followed by another injection of the vehicle after $30 \mathrm{~min}$. Group 2 (NAC-V group, $n=9$ ) received intraperitoneal (i.p.) injections of NAC (pretreatment, $100 \mathrm{mg} / \mathrm{kg}$, i.p. $\times 4$ ) followed by vehicle injections $30 \mathrm{~min}$ after. Group 3 (V-Preg group, $n=9$ ) received vehicle pretreatment $30 \mathrm{~min}$ before pregabalin injection $(60 \mathrm{mg} / \mathrm{kg}$, i.p. $\times 4)$. This dose of pregabalin was selected because it induced place preference in a previous study [13]. Moreover, pregabalin at low doses $(30 \mathrm{mg} / \mathrm{kg})$ or less is less effective than high doses are, which were reported in numerous case studies in inducing rewarding effects [44-48]. Lastly, Group 4 (NAC-Preg group, $n=8)$ received NAC pretreatment $(100 \mathrm{mg} / \mathrm{kg}$, i.p. $\times 4)$ $30 \mathrm{~min}$ before pregabalin injection $(60 \mathrm{mg} / \mathrm{kg}$, i.p. $\times 4)$. Following conditioning, mice were assessed for drug-seeking like behavior.

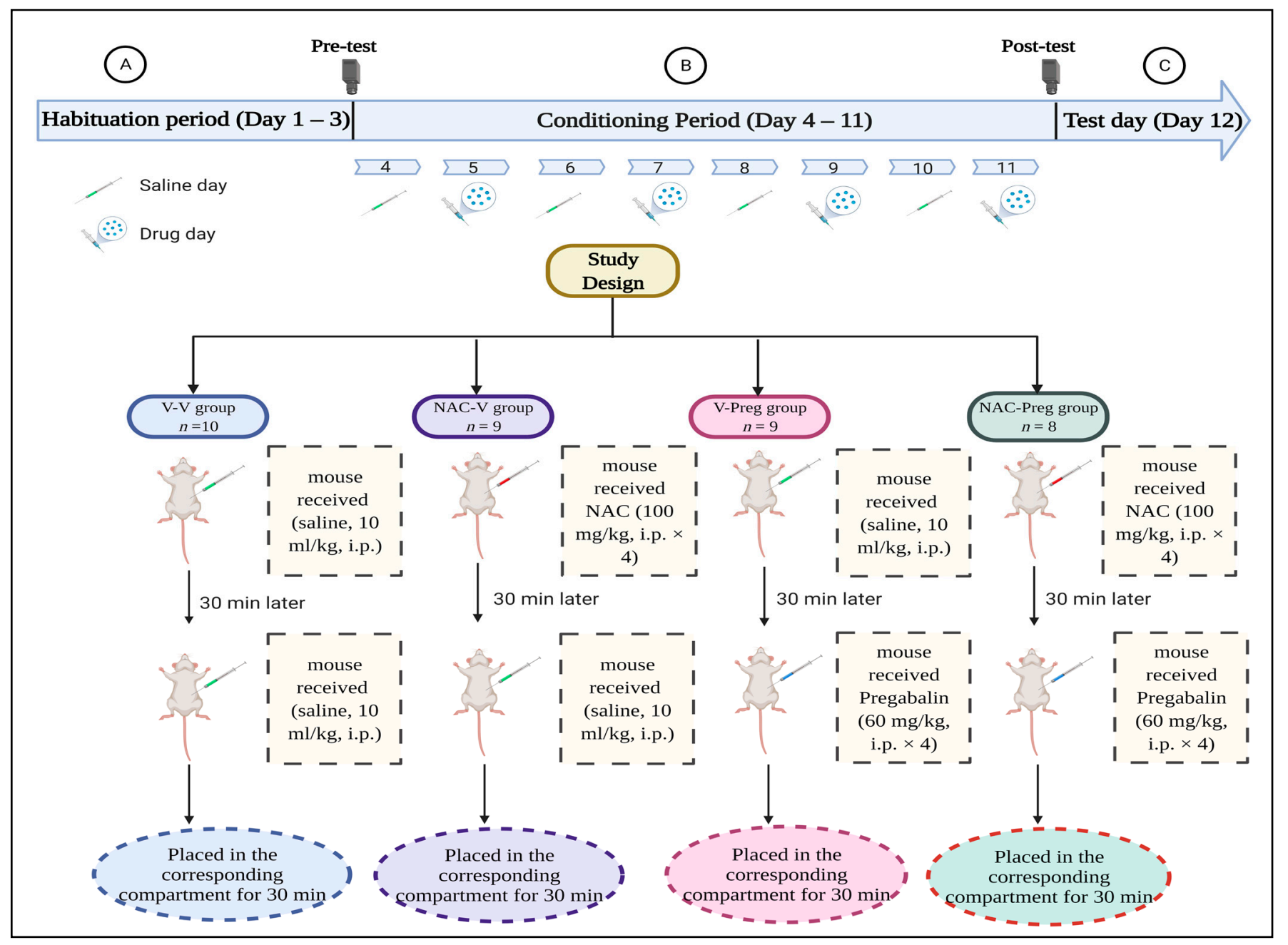

Figure 1. Experimental design to evaluate effect of N-acetylcysteine (NAC) on pregabalin-induced conditioned place preference (CPP). (A) Each mouse was permitted to explore both conditioning compartments for 30 min and was tested at Day 3. (B) During the conditioning period, each mouse received two injections/day of either saline or NAC (100 mg/ kg) in the home cage as a $30 \mathrm{~min}$ pretreatment, followed by pregabalin $(60 \mathrm{mg} / \mathrm{kg})$ or vehicle. The next day, each mouse received two injections / day of only the vehicle as pre- and post- treatment, and that was repeated for 8 days. (C) At Day 12, post-test was conducted.

\subsubsection{CPP Model Apparatus}

The CPP apparatus was produced from acrylic material. The apparatus contained two conditioning compartments that were identical in size $(35 \times 35 \times 50 \mathrm{~cm})$, and one external start box $(10 \times 15 \times 10 \mathrm{~cm})$ as previously explained [13]. Compartments were marked with distinctive visual and tactile cues. The first compartment had round holes in its 
flooring and rough white walls lined with horizontal black stripes. The other compartment had flooring with rectangular holes and smooth black walls that were lined with white vertical stripes.

\subsubsection{Habituation Period}

The habituation period consisted of 3 days. Each mouse was placed in the start box with a closed gate for $3 \mathrm{~min}$. Thereafter, each mouse was permitted to explore both conditioning compartments for $30 \mathrm{~min}$. On Day 3, mice were allowed to freely explore both conditioning compartments. The experiment was recorded with a digital camera, and time spent was calculated using ANY-maze software (Stoelting Co; Wood Dale, IL, USA). The unbiased method for assigning groups was implemented. If a mouse stayed in one compartment for $>67 \%$ of total test time, that mouse was excluded from the study [49-51]. According to this criterion, 4 mice were excluded due to increased initial preference. This step was performed to determine the unbiased preference baseline $[52,53]$. The mice were then randomly assigned to 1 of the 4 groups.

\subsubsection{Conditioning Period}

Following the habituation period, each mouse was administered its treatment (i.p. $\times 4$ ) according to the group assigned throughout the conditioning period (Days 4-11). The mice were administered an injection of either saline or $100 \mathrm{mg} / \mathrm{kg}$ NAC $30 \mathrm{~min}$ beforehand as pretreatment, and then given either pregabalin or vehicle as posttreatment, placed in one of the closed compartments (pregabalin-paired), and allowed to explore for $30 \mathrm{~min}$. The next day, the mice received vehicle injections as pretreatment and post-treatment and were placed in the other closed conditioning compartment (vehicle-paired) for $30 \mathrm{~min}$. This procedure was repeated for 8 days.

The postconditioning test was conducted on Day 12, when each mouse was allowed to travel freely in both the compartments for $30 \mathrm{~min}$. This experiment was also recorded with a digital camera, and the time each mouse spent in both compartments was measured using ANY-maze software (Stoelting, Wood Dale, IL, USA)

\subsection{Statistical Analysis}

Two-way ANOVA with repeated measures (time $\times$ compartment) was used for the evaluation of the time spent in the pregabalin- or saline-paired chamber during the habituation and conditioning periods. This statistical analysis was chosen on the basis of previous studies [39,50,51,54-56]. When significant effects were discovered, Tukey's multiple comparison post hoc test was applied. Data were analyzed using GraphPad Prism (GraphPad Software, San Diego, CA, USA), with the level of significance set at $p<0.05$.

\section{Results}

In Group 1, which was the control group where animals received saline, there were no significant differences with regard to time $\left(\mathrm{F}_{1,9}=0.002922, p=0.9581\right)$, compartment $\left(\mathrm{F}_{1,9}=0.02993, p=0.8665\right)$, or interaction between time and compartment $\left(\mathrm{F}_{1,9}=0.0006267\right.$, $p=0.9806$ ) during the conditioning phase, as shown in Figure 2a. In Group 2, where the animals received NAC $(100 \mathrm{mg} / \mathrm{kg})$, the effect of NAC on CPP was studied. Pretreatment with NAC did not affect CPP. Statistical analyses revealed no significant effects of NAC on time $\left(\mathrm{F}_{1,8}=3.053, p=0.1187\right)$, compartment $\left(\mathrm{F}_{1,8}=0.1971, p=0.6688\right)$, or interaction between time and compartment $\left(\mathrm{F}_{1,8}=0.008029, p=0.9308\right)$ during the conditioning period, as shown in Figure $2 \mathrm{~b}$. In Group 3, where the animals received pregabalin $(60 \mathrm{mg} / \mathrm{kg})$, the effect of pregabalin on CPP was studied, and pregabalin had induced CPP at a dose of $60 \mathrm{mg}$. Statistical analysis displayed a significant effect on compartment $\left(\mathrm{F}_{1,8}=6.344, p=0.0359\right)$ and significant interaction between time and compartment $\left(\mathrm{F}_{1,8}=51.75, p<0.0001\right)$, but there were no significant differences with regard to phases $\left(\mathrm{F}_{1,8}=1.146, p=0.3157\right)$. Tukey's test revealed no significant difference in time spent when comparing the pregabalin- and vehicle-paired compartments in the pretest ( $p=0.8958$; Figure 3a). However, time spent in 
the pregabalin-paired compartment was significantly higher than that spent in the vehiclepaired compartment in the post-test $(p<0.01$; Figure $3 \mathrm{a})$. In addition, time spent in the pregabalin-paired compartment was higher in the post-test as compared to in the pretest ( $p=0.0042$; Figure 3a). Lastly, in Group 4, where mice were given NAC pretreatment and were then subjected to pregabalin, no significant changes were revealed in time $\left(\mathrm{F}_{1,7}=1.000, p=0.3506\right)$, compartment $\left(\mathrm{F}_{1,7}=0.01108, p=0.9191\right)$, or interaction between time and compartment $\left(\mathrm{F}_{1,7}=0.04368, p=0.8404\right.$; Figure $\left.3 \mathrm{~b}\right)$ in the pre- and post-test.

a)

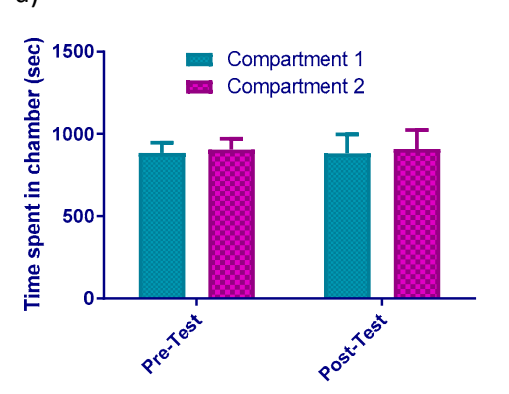

b)

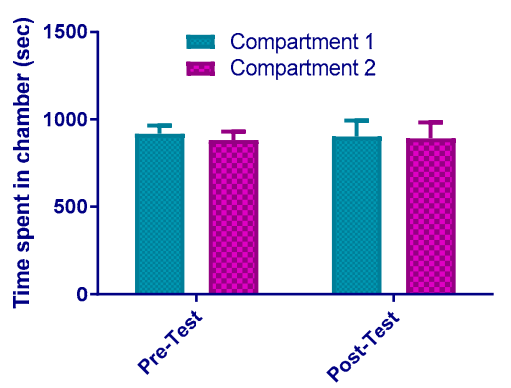

Figure 2. (a) Effect of vehicle on CPP. Time spent (mean \pm SEM) of vehicle-treated groups was examined. There was no significant difference in time spent in pre- and post-test in control group. (b) Effect of NAC on CPP. Time spent (mean $\pm \mathrm{SEM}$ ) did not significantly change in the vehicle- and NAC-treated groups in the pre- and post-test.

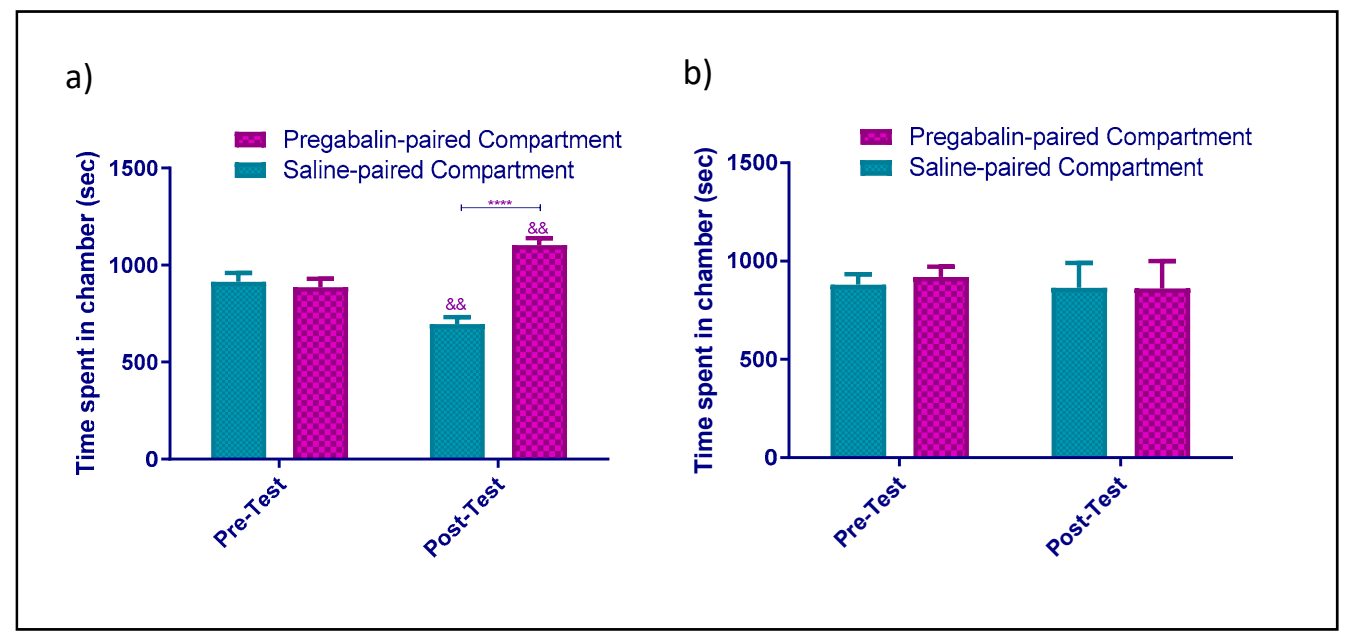

Figure 3. (a) Effect of pregabalin $(60 \mathrm{mg} / \mathrm{kg})$ on CPP. Time spent in pregabalin-paired compartment was significantly higher than that spent in the vehicle-paired compartment in the post-test. Time spent was significantly increased in the pregabalin-paired compartment post-test when compared to the saline and pregabalin-paired compartment pretest. (b) Effect of NAC-pretreatment on pregabalin-induced CPP. Time spent (mean \pm SEM) was not significantly changed in pregabalin-paired compartment as compared to the vehicle-paired compartment pre- and post-test. ${ }^{* * * *}: p<0.0001$; $(\& \&: p<0.01)$.

\section{Discussion}

Pregabalin at low doses $(30 \mathrm{mg} / \mathrm{kg}$ ) or less is less effective than high doses are, which were reported in numerous case studies in inducing rewarding effects [44-48]. Previous reports on animal models revealed that a low dose of pregabalin (up to $30 \mathrm{mg} / \mathrm{kg}$ ) did not induce the CPP model. In humans, standard doses of pregabalin range from 75 to $600 \mathrm{mg} /$ day [57], and patients who experience euphoria and withdrawal symptoms were 
reported to abuse pregabalin by taking larger quantities or using it for a longer time than that prescribed [9-12]. Consistent with this, one study found that the CPP in a mouse model was induced using higher doses of pregabalin (60 and $90 \mathrm{mg} / \mathrm{kg}$ ) [13]. The consistency of the results supported the validity of using these doses in animal experiments to test the reward-seeking properties of pregabalin. In this study, as expected, a $60 \mathrm{mg} / \mathrm{kg}$ dose of pregabalin induced drug-seeking behavior in a CPP mouse model of drug addiction (Figure 3a).

Pregabalin decreases the release of glutamate and reduces the activation of the AMPA receptor [58-60]. In a tooth-pain model, the release of glutamate, which was induced by mustard oil, was blocked by the systemic administration of pregabalin [61]. Furthermore, another study demonstrated that the release of glutamate was decreased in the medullary dorsal horn by the administration of pregabalin in a rodent model [62]. Other evidence from rodent model studies showed that pregabalin reduces neuropathic pain by inhibiting the release of glutamate in the spinal cord [63]. A 2013 study showed that the reduction in glutamate and glutamine release was attributed to pain reduction, and a reduction in brain connectivity was observed using neuroimaging [64]. Another mechanism that involves the augmentation of glutamate transporter activity [65] and a reduction in neuronal plasticity was suggested for pregabalin analgesic properties [66]. In contrast to our study, these experiments used a low dose of pregabalin $(10-30 \mathrm{mg} / \mathrm{kg})$ or a neuropathic pain model. In our study, a high dose of pregabalin was found to induce CPP, and it was speculated that the concentration of glutamate had probably increased. Therefore, another study is warranted to specifically determine the effects of high doses of pregabalin on the release of the GLT-1 receptor and glutamate.

The mechanism by which pregabalin induces drug-seeking like behavior is poorly understood. However, the glutamatergic system was implicated in drug-seeking behavior $[17,19]$. Glial excitatory amino acid transporter GLT-1 is the primary regulator of glutamatergic homeostasis in the brain [15], and many studies linked glutamatergic imbalance in the NAcc along with GLT-1 downregulation to drug-seeking behavior [67-69]. For instance, the downregulation of GLT-1 expression is associated with cocaine-seeking behavior [70]. Moreover, this glutamatergic-system disturbance is associated with glutamate spillover as glutamate uptake from the synapse decreases [71]. Furthermore, elevated glutamate concentration at the synapses leads to the potentiation and enhancement of many receptors (e.g., mGlu 5 and NMDA) that increase drug-seeking behavior in mice [71]. Pregabalin (60 mg/kg)-induced CPP might occur in part due to the downregulation of xCT and GLT-1 expression, which increases glutamate concentration at the synapses. One limitation of this study is that GLT- 1 and xCT expression levels were not measured; therefore, additional studies are warranted to investigate molecular changes in GLT-1 and xCT in pregabalin-induced drug-seeking-like effects.

Another possible mechanism of pregabalin-induced seeking behavior might be due to its effects on mGlu2/3 receptors, which are presynaptically expressed. These presynaptic receptors are involved in reward- and drug-seeking behavior by controlling the release of glutamate in the NAcc and prefrontal cortex [72]. The activation of the mGlu2/3 receptor reverses drug-seeking behavior by blocking the release of glutamate [71], whereas antagonists of these receptors increase the release of glutamate in the NAcc [73]. Pregabalin may work by causing an initial decrease in the release of glutamate, which may then lead to the desensitization or downregulation of these presynaptic mGlu2/3 receptors [73]. These neuroadaptations and impaired $\mathrm{mGlu2} / 3$ functions were reported following repeated exposure to several drugs of abuse [74]. Moreover, in our current study, NAC blocked the pregabalin-induced CPP, which may have been due to its improvement of glutamatergic tone on the presynaptic mGlu2/3 receptors [33,75]. Additional studies are warranted to study the molecular changes of $\mathrm{mGlu2} / 3$ in response to the pregabalin-induced CPP.

NAC is an effective treatment, especially in cocaine-free patients [29,30]. Furthermore, prolonged treatment with NAC restores the expression levels of GLT-1 and xCT, and reduces drug-seeking behavior [32,33]. Along with its potentially therapeutic effects 
regarding drug abuse, NAC may be used to treat different neurological diseases, such as Alzheimer's disease and bipolar disorder, which may involve the glutamatergic system [76]. For instance, pretreatment with NAC in rats with ischemic stroke can restore GLT-1 expression; hence, NAC treatment may prevent the glutamate-induced neurotoxicity observed in these neurological diseases [77]. Taken together, these studies suggest that NAC can reverse the neurophysiological changes induced by drug abuse $[28,78]$. Additionally, drug-abuse treatment with NAC is more promising than other treatments are due to its unique therapeutic potential and relative safety. Moreover, pretreatment with NAC $(100 \mathrm{mg} / \mathrm{kg})$ is effective in preventing pregabalin-induced seeking.

Alternate mechanisms associated with the therapeutic potential of NAC in neurological disorders need to be elucidated [77] and may involve its antioxidant properties $[40,79,80]$. GSH engages in the enzymatic and nonenzymatic detoxification of reactive oxygen species (ROS) [81]. Additionally, NAC, which is a GSH precursor, scavenges ROS in neurons [82] and stabilizes the oxidative status by countering oxidative-stress markers (e.g., nitric oxide and superoxide radicals) [83,84]. Many studies also connected glutamate neurotoxicity in drug abuse with increased oxidative stress [85], and NAC could improve the oxidative-stress profile of rats exposed to alcohol [49,86,87]. Additional studies are warranted to further study the role of NAC on oxidative-stress markers in pregabalin-induced CPP.

Another limitation of this study is that the treatment group (NAC-Preg) was not directly compared with the pregabalin group. However, the group was treated with NAC did not show a preference for the drug-paired compartment, which can be attributed to the blocking effect of NAC on pregabalin. On the other hand, a strength of this study was the use of the unbiased CPP paradigm, which required that each animal spend less than $67 \%$ of total time in one compartment during the pretest period. Therefore, mice were excluded if they spent more than $67 \%$ of the total time in one compartment. The unbiased paradigm was used to avoid any impact of the CPP flooring or walls and improve the accurate assessment of conditioning cues. Another strength of our study is that two-way ANOVA with repeated measures was utilized for CPP data. Different within-group variables can affect CPP $[41,42,88]$. Cunningham et al. explored this issue and found a significant interaction between groups and other variables that could alter the interpretation of CPP data $[41,42,88]$. Therefore, a comparison between dependent variables was used to ensure the credibility of the results.

\section{Conclusions}

In conclusion, this study revealed for the first time that the administration of NAC reduced pregabalin-seeking behavior. The glutamatergic system was also proposed to be involved in this process. Further studies are warranted to confirm whether NAC-induced changes in GLT-1 or xCT expression levels represent contributing factors to the observed effects of NAC.

Author Contributions: Conceptualization, A.H.A. and Y.S.A.; methodology, A.H.A.; software, H.O.A.; validation, W.F.A., A.G., and O.A.; formal analysis, H.O.A. and A.A.; investigation, A.A., T.A.; resources, Q.A.; data curation, A.A., T.A.; writing-original-draft preparation, A.H.A.; writingreview and editing, Z.A.S.; visualization, A.A., A.M.G.H.; supervision, Y.S.A., and Z.A.S.; project administration, Y.S.A.; funding acquisition, Y.S.A. All authors have read and agreed to the published version of the manuscript.

Funding: The research was funded by the Deanship of Scientific Research, Taif University, Saudi Arabia, Research group grant number 1-439-6079.

Institutional Review Board Statement: The experimental protocol was officially approved by the Ethics Committee of Taif University (42-0112), and all experiments were conducted in accordance with the Institutional Animal Care and Use Committee of the National Institutes of Health guidelines.

Informed Consent Statement: Not applicable. 
Data Availability Statement: Available upon reasonable request.

Conflicts of Interest: The authors declare no conflict of interest.

\section{References}

1. Li, Z.; Taylor, C.P.; Weber, M.; Piechan, J.; Prior, F.; Bian, F.; Cui, M.; Hoffman, D.; Donevan, S. Pregabalin is a potent and selective ligand for $\alpha 2 \delta-1$ and $\alpha 2 \delta-2$ calcium channel subunits. Eur. J. Pharmacol. 2011, 667, 80-90. [CrossRef] [PubMed]

2. Pexton, T.; Moeller-Bertram, T.; Schilling, J.M.; Wallace, M.S. Targeting voltage-gated calcium channels for the treatment of neuropathic pain: A review of drug development. Expert Opin. Investig. Drugs 2011, 20, 1277-1284. [CrossRef] [PubMed]

3. Boschen, M.J. A meta-analysis of the efficacy of pregabalin in the treatment of generalized anxiety disorder. Can. J. Psychiatry 2011, 56, 558-566. [CrossRef] [PubMed]

4. Bağımlılı̆̆ı, P.; Oğuz, G.; Güven, F.M.; Batmaz, S. Pregabalin dependence: A case report. J. Depend. 2015, 16, 160-163.

5. Gahr, M.; Freudenmann, R.W.; Hiemke, C.; Kölle, M.A.; Schönfeldt-Lecuona, C. Pregabalin abuse and dependence in Germany: Results from a database query. Eur. J. Clin. Pharmacol. 2013, 69, 1335-1342. [CrossRef]

6. Halaby, A.; Kassm, S.A.; Naja, W.J. Pregabalin dependence: A case report. Curr. Drug Saf. 2015, 10, 184-186. [CrossRef]

7. Saudigazette. Saudi Youth and the Abuse of Prescription Drugs. Available online: http://saudigazette.com.sa/article/155386 /Saudi-youth-and-the-abuse-of-prescription-drugs (accessed on 13 February 2020).

8. Bassiony, M. Substance use disorders in Saudi Arabia. J. Subst. Use 2013, 18, 450-466. [CrossRef]

9. Carrus, D.; Schifano, F. Pregabalin misuse-related issues; intake of large dosages, drug-smoking allegations, and possible association with myositis: Two case reports. J. Clin. Psychopharmacol. 2012, 32, 839-840. [CrossRef]

10. Schifano, F. Misuse and abuse of pregabalin and gabapentin: Cause for concern? CNS Drugs 2014, 28, 491-496. [CrossRef] [PubMed]

11. Martinotti, G.; Lupi, M.; Sarchione, F.; Santacroce, R.; Salone, A.; De Berardis, D.; Serroni, N.; Cavuto, M.; Signorelli, M.; Aguglia, E. The potential of pregabalin in neurology, psychiatry and addiction: A qualitative overview. Curr. Pharm. Des. 2013, 19, 6367-6374. [CrossRef]

12. Gahr, M.; Freudenmann, R.W.; Kölle, M.A.; Schönfeldt-Lecuona, C. Pregabalin and addiction: Lessons from published cases. J. Subst. Use 2014, 19, 448-449. [CrossRef]

13. Althobaiti, Y.S.; Almalki, A.; Alsaab, H.; Alsanie, W.; Gaber, A.; Alhadidi, Q.; Hardy, A.M.G.; Nasr, A.; Alzahrani, O.; Stary, C.M. Pregabalin: Potential for addiction and a possible glutamatergic mechanism. Sci. Rep. 2019, 9, 1-8. [CrossRef]

14. Reissner, K.J.; Gipson, C.D.; Tran, P.K.; Knackstedt, L.A.; Scofield, M.D.; Kalivas, P.W. Glutamate transporter GLT-1 mediates N-acetylcysteine inhibition of cocaine reinstatement. Addict. Biol. 2015, 20, 316-323. [CrossRef] [PubMed]

15. Danbolt, N.C. Glutamate uptake. Prog. Neurobiol. 2001, 65, 1-105. [CrossRef]

16. Althobaiti, Y.S.; Alshehri, F.S.; Almalki, A.H.; Sari, Y. Effects of ceftriaxone on glial glutamate transporters in Wistar rats administered sequential ethanol and methamphetamine. Front. Neurosci. 2016, 10, 427. [CrossRef]

17. Das, S.C.; Yamamoto, B.K.; Hristov, A.M.; Sari, Y. Ceftriaxone attenuates ethanol drinking and restores extracellular glutamate concentration through normalization of GLT-1 in nucleus accumbens of male alcohol-preferring rats. Neuropharmacology 2015, 97, 67-74. [CrossRef]

18. Knackstedt, L.A.; Melendez, R.I.; Kalivas, P.W. Ceftriaxone restores glutamate homeostasis and prevents relapse to cocaine seeking. Biol. Psychiatry 2010, 67, 81-84. [CrossRef]

19. Dravolina, O.A.; Zakharova, E.S.; Shekunova, E.V.; Zvartau, E.E.; Danysz, W.; Bespalov, A.Y. mGlu1 receptor blockade attenuates cue-and nicotine-induced reinstatement of extinguished nicotine self-administration behavior in rats. Neuropharmacology 2007, 52, 263-269. [CrossRef]

20. Tessari, M.; Pilla, M.; Andreoli, M.; Hutcheson, D.M.; Heidbreder, C.A. Antagonism at metabotropic glutamate 5 receptors inhibits nicotine-and cocaine-taking behaviours and prevents nicotine-triggered relapse to nicotine-seeking. Eur. J. Pharmacol. 2004, 499, 121-133. [CrossRef]

21. Lee, B.; Platt, D.M.; Rowlett, J.K.; Adewale, A.S.; Spealman, R.D. Attenuation of behavioral effects of cocaine by the metabotropic glutamate receptor 5 antagonist 2-methyl-6-(phenylethynyl)-pyridine in squirrel monkeys: Comparison with dizocilpine. $J$. Pharmacol. Exp. Ther. 2005, 312, 1232-1240. [CrossRef]

22. Koob, G.F.; Volkow, N.D. Neurocircuitry of addiction. Neuropsychopharmacology 2009, 35, 217-238. [CrossRef] [PubMed]

23. Cornish, J.L.; Kalivas, P.W. Glutamate transmission in the nucleus accumbens mediates relapse in cocaine addiction. J. Neurosci. 2000, 20, RC89. [CrossRef] [PubMed]

24. Park, W.K.; Bari, A.; Jey, A.; Anderson, S.; Spealman, R.; Rowlett, J.; Pierce, R. Cocaine administered into the medial prefrontal cortex reinstates cocaine-seeking behavior by increasing AMPA receptor-mediated glutamate transmission in the nucleus accumbens. J. Neurosci. 2002, 22, 2916-2925. [CrossRef] [PubMed]

25. McFarland, K.; Davidge, S.B.; Lapish, C.C.; Kalivas, P.W. Limbic and motor circuitry underlying footshock-induced reinstatement of cocaine-seeking behavior. J. Neurosci. 2004, 24, 1551-1560. [CrossRef]

26. Bäckström, P.; Hyytiä, P. Involvement of AMPA/kainate, NMDA, and mGlu5 receptors in the nucleus accumbens core in cue-induced reinstatement of cocaine seeking in rats. Psychopharmacology 2007, 192, 571-580. [CrossRef]

27. McClure, E.A.; Gipson, C.D.; Malcolm, R.J.; Kalivas, P.W.; Gray, K.M. Potential role of N-acetylcysteine in the management of substance use disorders. CNS Drugs 2014, 28, 95-106. [CrossRef] [PubMed] 
28. Moussawi, K.; Pacchioni, A.; Moran, M.; Olive, M.F.; Gass, J.T.; Lavin, A.; Kalivas, P.W. N-Acetylcysteine reverses cocaine-induced metaplasticity. Nat. Neurosci. 2009, 12, 182-189. [CrossRef]

29. LaRowe, S.D.; Mardikian, P.; Malcolm, R.; Myrick, H.; Kalivas, P.; McFarland, K.; Saladin, M.; McRae, A.; Brady, K. Safety and tolerability of $\mathrm{N}$-acetylcysteine in cocaine-dependent individuals. Am. J. Addict. 2006, 15, 105-110. [CrossRef]

30. Knackstedt, L.A.; LaRowe, S.; Mardikian, P.; Malcolm, R.; Upadhyaya, H.; Hedden, S.; Markou, A.; Kalivas, P.W. The role of cystine-glutamate exchange in nicotine dependence in rats and humans. Biol. Psychiatry 2009, 65, 841-845. [CrossRef]

31. LaRowe, S.D.; Kalivas, P.W.; Nicholas, J.S.; Randall, P.K.; Mardikian, P.N.; Malcolm, R.J. A double-blind placebo-controlled trial of $\mathrm{N}$-acetylcysteine in the treatment of cocaine dependence. Am. J. Addict. 2013, 22, 443-452. [CrossRef]

32. Ducret, E.; Puaud, M.; Lacoste, J.; Belin-Rauscent, A.; Fouyssac, M.; Dugast, E.; Murray, J.E.; Everitt, B.J.; Houeto, J.L.; Belin, D. N-acetylcysteine Facilitates Self-Imposed Abstinence After Escalation of Cocaine Intake. Biol. Psychiatry 2016, 80, 226-234. [CrossRef]

33. Baker, D.A.; McFarland, K.; Lake, R.W.; Shen, H.; Tang, X.C.; Toda, S.; Kalivas, P.W. Neuroadaptations in cystine-glutamate exchange underlie cocaine relapse. Nat. Neurosci. 2003, 6, 743-749. [CrossRef]

34. Zhou, W.; Kalivas, P.W. N-acetylcysteine reduces extinction responding and induces enduring reductions in cue-and heroininduced drug-seeking. Biol. Psychiatry 2008, 63, 338-340. [CrossRef] [PubMed]

35. Amen, S.L.; Piacentine, L.B.; Ahmad, M.E.; Li, S.J.; Mantsch, J.R.; Risinger, R.C.; Baker, D.A. Repeated N-acetyl cysteine reduces cocaine seeking in rodents and craving in cocaine-dependent humans. Neuropsychopharmacology 2011, 36, 871. [CrossRef]

36. Xi, Z.X.; Kiyatkin, M.; Li, X.; Peng, X.Q.; Wiggins, A.; Spiller, K.; Li, J.; Gardner, E.L. N-acetylaspartylglutamate (NAAG) inhibits intravenous cocaine self-administration and cocaine-enhanced brain-stimulation reward in rats. Neuropharmacology 2010, 58, 304-313. [CrossRef] [PubMed]

37. Berk, M.; Malhi, G.S.; Gray, L.J.; Dean, O.M. The promise of N-acetylcysteine in neuropsychiatry. Trends Pharmacol. Sci. 2013, 34, 167-177. [CrossRef]

38. Brown, R.M.; Kupchik, Y.M.; Kalivas, P.W. The story of glutamate in drug addiction and of N-acetylcysteine as a potential pharmacotherapy. Jama Psychiatry 2013, 70, 895-897. [CrossRef] [PubMed]

39. Tzschentke, T.M.; Schmidt, W.J. N-methyl-D-aspartic acid-receptor antagonists block morphine-induced conditioned place preference in rats. Neurosci. Lett. 1995, 193, 37-40. [CrossRef]

40. He, Z.; Chen, Y.; Dong, H.; Su, R.; Gong, Z.; Yan, L. Inhibition of vesicular glutamate transporters contributes to attenuate methamphetamine-induced conditioned place preference in rats. Behav. Brain Res. 2014, 267, 1-5. [CrossRef] [PubMed]

41. Cunningham, C.L.; Gremel, C.M.; Groblewski, P.A. Drug-induced conditioned place preference and aversion in mice. Nat. Protoc. 2006, 1, 1662. [CrossRef]

42. Cunningham, C.L.; Ferree, N.K.; Howard, M.A. Apparatus bias and place conditioning with ethanol in mice. Psychopharmacology 2003, 170, 409-422. [CrossRef]

43. Tzschentke, T.M. Measuring reward with the conditioned place preference paradigm: A comprehensive review of drug effects, recent progress and new issues. Prog. Neurobiol. 1998, 56, 613-672. [CrossRef]

44. Aldemir, E.; Altintoprak, A.E.; Coskunol, H. Pregabalin dependence: A case report. Turk. Psikiyatri Derg. 2015, 26, 217-220. [CrossRef] [PubMed]

45. Grosshans, M.; Mutschler, J.; Hermann, D.; Klein, O.; Dressing, H.; Kiefer, F.; Mann, K. Pregabalin abuse, dependence, and withdrawal: A case report. Am. J. Psychiatry 2010, 167, 869. [CrossRef]

46. Filipetto, F.A.; Zipp, C.P.; Coren, J.S. Potential for pregabalin abuse or diversion after past drug-seeking behavior. J. Am. Osteopath. Assoc. 2010, 110, 605-607.

47. Andrews, N.; Loomis, S.; Blake, R.; Ferrigan, L.; Singh, L.; McKnight, A.T. Effect of gabapentin-like compounds on development and maintenance of morphine-induced conditioned place preference. Psychopharmacology 2001, 157, 381-387. [CrossRef] [PubMed]

48. Ruttenl, K.; Vry, J.; Robens, A.; Tzschentke, T.M.; Kam, E.L. Dissociation of rewarding, anti-aversive and anti-nociceptive effects of different classes of anti-nociceptives in the rat. Eur. J. Pain 2011, 15, 299-305. [CrossRef] [PubMed]

49. Seiva, F.R.; Amauchi, J.F.; Rocha, K.K.; Ebaid, G.X.; Souza, G.; Fernandes, A.A.; Cataneo, A.C.; Novelli, E.L. Alcoholism and alcohol abstinence: $\mathrm{N}$-acetylcysteine to improve energy expenditure, myocardial oxidative stress, and energy metabolism in alcoholic heart disease. Alcohol 2009, 43, 649-656. [CrossRef] [PubMed]

50. Althobaiti, Y.S.; Almalki, A.H. Effects of environmental enrichment on reinstatement of methamphetamine-induced conditioned place preference. Behav. Brain Res. 2020, 379, 112372. [CrossRef] [PubMed]

51. Althobaiti, Y.S.; Alghorabi, A.; Alshehri, F.S.; Baothman, B.; Almalki, A.H.; Alsaab, H.O.; Alsanie, W.; Gaber, A.; Almalki, H.; Alghamdi, A.S. Gabapentin-induced drug-seeking-like behavior: A potential role for the dopaminergic system. Sci. Rep. 2020, 10, 1-8. [CrossRef]

52. Nakagawa, T.; Fujio, M.; Ozawa, T.; Minami, M.; Satoh, M. Effect of MS-153, a glutamate transporter activator, on the conditioned rewarding effects of morphine, methamphetamine and cocaine in mice. Behav. Brain Res. 2005, 156, 233-239. [CrossRef] [PubMed]

53. Fujio, M.; Nakagawa, T.; Sekiya, Y.; Ozawa, T.; Suzuki, Y.; Minami, M.; Satoh, M.; Kaneko, S. Gene transfer of GLT-1, a glutamate transporter, into the nucleus accumbens shell attenuates methamphetamine-and morphine-induced conditioned place preference in rats. Eur. J. Neurosci. 2005, 22, 2744-2754. [CrossRef] [PubMed] 
54. Althobaiti, Y.S.; Alshehri, F.S.; Hakami, A.Y.; Hammad, A.M.; Sari, Y. Effects of Clavulanic Acid Treatment on Reinstatement to Methamphetamine, Glial Glutamate Transporters, and mGluR 2/3 Expression in P Rats Exposed to Ethanol. J. Mol. Neurosci. 2019, 67, 1-15. [CrossRef] [PubMed]

55. Acquas, E.; Carboni, E.; Leone, P.; Di Chiara, G. SCH 23390 blocks drug-conditioned place-preference and place-aversion: Anhedonia (lack of reward) or apathy (lack of motivation) after dopamine-receptor blockade? Psychopharmacology 1989, 99, 151-155. [CrossRef] [PubMed]

56. Smith, B.; Amit, Z.; Splawinsky, J. Conditioned place preference induced by intraventricular infusions of acetaldehyde. Alcohol 1984, 1, 193-195. [CrossRef]

57. Freynhagen, R.; Strojek, K.; Griesing, T.; Whalen, E.; Balkenohl, M. Efficacy of pregabalin in neuropathic pain evaluated in a 12-week, randomised, double-blind, multicentre, placebo-controlled trial of flexible-and fixed-dose regimens. Pain 2005, 115, 254-263. [CrossRef]

58. Fink, K.; Dooley, D.J.; Meder, W.P.; Suman-Chauhan, N.; Duffy, S.; Clusmann, H.; Göthert, M.J.N. Inhibition of neuronal Ca2+ influx by gabapentin and pregabalin in the human neocortex. Neuropharmacology 2002, 42, 229-236. [CrossRef]

59. Errante, L.D.; Petroff, O.A. Acute effects of gabapentin and pregabalin on rat forebrain cellular GABA, glutamate, and glutamine concentrations. Seizure 2003, 12, 300-306. [CrossRef]

60. Sills, G.J. The mechanisms of action of gabapentin and pregabalin. Curr. Opin. Pharmacol. 2006, 6, 108-113. [CrossRef]

61. Narita, N.; Kumar, N.; Cherkas, P.S.; Chiang, C.Y.; Dostrovsky, J.O.; Coderre, T.J.; Sessle, B.J.J.N. Systemic pregabalin attenuates sensorimotor responses and medullary glutamate release in inflammatory tooth pain model. Neuroscience 2012, 218, 359-366. [CrossRef]

62. Kumar, N.; Cherkas, P.S.; Varathan, V.; Miyamoto, M.; Chiang, C.Y.; Dostrovsky, J.O.; Sessle, B.J.; Coderre, T.J. Systemic pregabalin attenuates facial hypersensitivity and noxious stimulus-evoked release of glutamate in medullary dorsal horn in a rodent model of trigeminal neuropathic pain. Neurochem. Int. 2013, 62, 831-835. [CrossRef]

63. Kumar, N.; Laferriere, A.; Yu, J.S.; Leavitt, A.; Coderre, T.J. Evidence that pregabalin reduces neuropathic pain by inhibiting the spinal release of glutamate. J. Neurochem. 2010, 113, 552-561. [CrossRef] [PubMed]

64. Harris, R.E.; Napadow, V.; Huggins, J.P.; Pauer, L.; Kim, J.; Hampson, J.; Sundgren, P.C.; Foerster, B.; Petrou, M.; Schmidt-Wilcke, T.; et al. Pregabalin rectifies aberrant brain chemistry, connectivity, and functional response in chronic pain patients. Anesthesiology 2013, 119, 1453-1464. [CrossRef] [PubMed]

65. Ryu, J.H.; Lee, P.B.; Kim, J.H.; Do, S.H.; Kim, C.S. Effects of pregabalin on the activity of glutamate transporter type 3. Br. J. Anaesth. 2012, 109, 234-239. [CrossRef] [PubMed]

66. Anderson, C.M.; Swanson, R.A.J.G. Astrocyte glutamate transport: Review of properties, regulation, and physiological functions. Gila 2000, 32, 1-14. [CrossRef]

67. Gipson, C.D.; Reissner, K.J.; Kupchik, Y.M.; Smith, A.C.; Stankeviciute, N.; Hensley-Simon, M.E.; Kalivas, P.W. Reinstatement of nicotine seeking is mediated by glutamatergic plasticity. Proc. Natl. Acad. Sci. USA 2013, 110, 9124-9129. [CrossRef] [PubMed]

68. Kalivas, P.W.; McFarland, K.; Bowers, S.; Szumlinski, K.; Xi, Z.X.; Baker, D. Glutamate transmission and addiction to cocaine. Ann. N. Y. Acad. Sci. 2003, 1003, 169-175. [CrossRef]

69. Sari, Y.; Sreemantula, S.N.; Lee, M.R.; Choi, D.S. Ceftriaxone treatment affects the levels of GLT1 and ENT1 as well as ethanol intake in alcohol-preferring rats. J. Mol. Neurosci. 2013, 51, 779-787. [CrossRef]

70. Fischer-Smith, K.D.; Houston, A.C.; Rebec, G.V. Differential effects of cocaine access and withdrawal on glutamate type 1 transporter expression in rat nucleus accumbens core and shell. Neuroscience 2012, 210, 333-339. [CrossRef]

71. Kalivas, P.W. The glutamate homeostasis hypothesis of addiction. Nat. Rev. Neurosci. 2009, 10, 561-572. [CrossRef]

72. Moussawi, K.; Kalivas, P.W. Group II metabotropic glutamate receptors (mGlu2/3) in drug addiction. Eur. J. Pharmacol. 2010, 639, 115-122. [CrossRef]

73. Melendez, R.I.; Vuthiganon, J.; Kalivas, P.W. Regulation of extracellular glutamate in the prefrontal cortex: Focus on the cystine glutamate exchanger and group I metabotropic glutamate receptors. J. Pharmacol. Exp. Ther. 2005, 314, 139-147. [CrossRef] [PubMed]

74. Robbe, D.; Bockaert, J.; Manzoni, O.J. Metabotropic glutamate receptor 2/3-dependent long-term depression in the nucleus accumbens is blocked in morphine withdrawn mice. Eur. J. Neurosci. 2002, 16, 2231-2235. [CrossRef]

75. Madayag, A.; Lobner, D.; Kau, K.S.; Mantsch, J.R.; Abdulhameed, O.; Hearing, M.; Grier, M.D.; Baker, D.A. Repeated Nacetylcysteine administration alters plasticity-dependent effects of cocaine. J. Neurosci. 2007, 27, 13968-13976. [CrossRef] [PubMed]

76. Slattery, J.; Kumar, N.; Delhey, L.; Berk, M.; Dean, O.; Spielholz, C.; Frye, R. Clinical trials of N-acetylcysteine in psychiatry and neurology: A systematic review. Neurosci. Biobehav. Rev. 2015, 55, 294-321.

77. Krzyżanowska, W.; Pomierny, B.; Bystrowska, B.; Pomierny-Chamioło, L.; Filip, M.; Budziszewska, B.; Pera, J. Ceftriaxone-and $\mathrm{N}$-acetylcysteine-induced brain tolerance to ischemia: Influence on glutamate levels in focal cerebral ischemia. PLoS ONE 2017, 12, e0186243. [CrossRef]

78. Kalivas, P.; Volkow, N. New medications for drug addiction hiding in glutamatergic neuroplasticity. Mol. Psychiatry 2011, 16, 974. [CrossRef] [PubMed]

79. Dhouib, I.E.; Jallouli, M.; Annabi, A.; Gharbi, N.; Elfazaa, S.; Lasram, M.M. A minireview on N-acetylcysteine: An old drug with new approaches. Life Sci. 2016, 151, 359-363. [CrossRef] 
80. Samuni, Y.; Goldstein, S.; Dean, O.M.; Berk, M. The chemistry and biological activities of N-acetylcysteine. Biochim. Biophys. Acta (BBA) Gen. Subj. 2013, 1830, 4117-4129. [CrossRef]

81. Robaczewska, J.; Kedziora-Kornatowska, K.; Kozakiewicz, M.; Zary-Sikorska, E.; Pawluk, H.; Pawliszak, W.; Kedziora, J. Role of glutathione metabolism and glutathione-related antioxidant defense systems in hypertension. J. Physiol. Pharmacol. 2016, 67, 331-337.

82. Sözbir, E.; Nazıroğlu, M. Diabetes enhances oxidative stress-induced TRPM2 channel activity and its control by N-acetylcysteine in rat dorsal root ganglion and brain. Metab. Brain Dis. 2016, 31, 385-393. [CrossRef] [PubMed]

83. Naik, A.K.; Tandan, S.K.; Dudhgaonkar, S.P.; Jadhav, S.H.; Kataria, M.; Prakash, V.R.; Kumar, D. Role of oxidative stress in pathophysiology of peripheral neuropathy and modulation by $\mathrm{N}$-acetyl-1-cysteine in rats. Eur. J. Pain 2006, 10, 573. [CrossRef] [PubMed]

84. Horst, A.; Kolberg, C.; Moraes, M.S.; Riffel, A.P.K.; Finamor, I.A.; Belló-Klein, A.; Pavanato, M.A.; Partata, W.A. Effect of $\mathrm{N}$-acetylcysteine on the spinal-cord glutathione system and nitric-oxide metabolites in rats with neuropathic pain. Neurosci. Lett. 2014, 569, 163-168. [CrossRef] [PubMed]

85. Tata, D.A.; Yamamoto, B.K. Interactions between methamphetamine and environmental stress: Role of oxidative stress, glutamate and mitochondrial dysfunction. Addiction 2007, 102, 49-60. [CrossRef] [PubMed]

86. Ozaras, R.; Tahan, V.; Aydin, S.; Uzun, H.; Kaya, S.; Senturk, H. N-acetylcysteine attenuates alcohol-induced oxidative stress in the rat. World J. Gastroenterol. 2003, 9, 125-128. [CrossRef] [PubMed]

87. Schneider, R.; Bandiera, S.; Souza, D.G.; Bellaver, B.; Caletti, G.; Quincozes-Santos, A.; Elisabetsky, E.; Gomez, R. N-acetylcysteine prevents alcohol related neuroinflammation in rats. Neurochem. Res. 2017, 42, 2135-2141. [CrossRef] [PubMed]

88. Bevins, R.; Cunningham, C. Tasks and techniques. In A Sampling of the Methodologies for the Investigation of Animal Learning, Behavior and Cognition; Anderson, M.J., Ed.; Nova Science Publishers: Hauppauge, NY, USA, 2006. 